\title{
The Supreme Court, the Media, and Public Opinion: Comparing Experimental and Observational Methods
}

\author{
Katerina Linos and Kimberly Twist
}

\begin{abstract}
Can Supreme Court rulings change Americans' policy views? Prior experimental and observational studies come to conflicting conclusions because of methodological limitations. We argue that existing studies overlook the media's critical role in communicating Court decisions and theorize that major decisions change Americans' opinions most when the media offer one-sided coverage supportive of the Court majority. We fielded nationally representative surveys shortly before and after two major Supreme Court decisions on health care and immigration and connected our public opinion data with six major television networks' coverage of each decision. We find that Court decisions can influence national opinion and increase support for policies the Court upholds as constitutional. These effects were largest among people who received one-sided information. To address selection concerns, we combined this observational study with an experiment and find that people who first heard about the Court decisions through the media and through the experiment responded in similar ways.
\end{abstract}

\section{INTRODUCTION}

Can rulings from the Supreme Court, the most trusted branch of the federal government, change citizens' views so they support its decisions? Can hearing about a Court ruling prompt Americans to believe that particular

KATERINA linos is Professor of Law at the University of California, Berkeley. KIMBERLY TWIST is Assistant Professor of Political Science at San Diego State University. We thank Kathy Abrams, Stephen Ansolabehere, Omri Ben-Shahar, Adam Chilton, Jack Citrin, Maria Echaveste, Chris Edley, Chris Elmendorf, Dan Farber, Stavros Gadinis, Jacob Gersen, Stephen Goggin, Tom Goldstein, David Hoffman, Taeku Lee, Gabriel Lenz, Ian Haney Lopez, Robert MacCoun, Aila Matanock, Justin McCrary, Tom Miles, Jacob Montgomery, Anne O'Connell, Nate Persily, Victoria Plaut, Alison Post, Kevin Quinn, Gerald Rosenberg, Bertrall Ross, David Sklansky, Fred Smith, Holger Spamann, Matthew Stephenson, Laura Stoker, Mike Tomz, Cecillia Wang, Chuck Weisselberg, and John Yoo for their generous advice. We are also very grateful to the Hellman Family Fund and

[Journal of Legal Studies, vol. 45 (June 2016)]

(C) 2016 by The University of Chicago. All rights reserved. 0047-2530/2016/4502-0008 $\$ 10.00$ 
policies are consistent (or inconsistent) with deeply held constitutional values and thus increase (or decrease) overall support for these policies? Multiple observational studies in real-life settings answer no and find that Court rulings have no net impact on national opinion (for example, Marshall 1987; Rosenberg 1991; Hanley 2008; Le and Citrin 2008; Luks and Salamone 2008; Gash and Gonzales 2008) but sometimes polarize opinions (for example, Franklin and Kosaki 1989; Hoekstra and Segal 1996; Johnson and Martin 1998; Brickman and Peterson 2006). In contrast, a few experimental studies answer yes and report that the American public increases its support for policies the Supreme Court upholds (for example, Bartels and Mutz 2009; Hoekstra 1995; Clawson, Kegler, and Waltenburg 2001).

Resolving this quandary is critical both for our understanding of the role of the judiciary in democratic politics and for our understanding of public opinion formation more generally. If Supreme Court rulings can provide a cue for Americans to follow, leading them to accept initially unpopular positions, then the Court can function as a "republican schoolmaster" and as an effective vehicle for social change (Dahl 1957; Caldeira 1986; Franklin and Kosaki 1989; Tushnet 2005). If Court decisions resonate with ordinary Americans, then these decisions are less likely to meet hostility and resistance from officials called on to implement them, which in turn helps guarantee both judicial independence and an effective system of checks and balances more generally (Stephenson 2004; Fox and Stephenson 2011). Finally, if initially unpopular Court rulings gain acceptance over time, this can help counter the major normative challenge to the Court's legitimacy: that the Court is a countermajoritarian and unresponsive body composed of unelected judges with life tenure (Ackerman 1991; Kramer 2004). In contrast, if Americans do not respond to Court rulings, or are polarized by them, then each of these claims is, at best, a "hollow hope" (Rosenberg 1991).

By improving on measurement techniques that complicate prior studies in real-life settings, we find that Court rulings can change national public opinion, even on controversial issues that have been extensively debated and on which Americans have relatively firm views. But we also explain why our study and many others document a great diversity of

the Warren Institute for financial support and to Annie Hilby, Juliana Stivanicevic, and May Whitaker for excellent research assistance. We also thank the editors and an anonymous reviewer for their thoughtful comments and Samantha Luks and Ashley Grosse at YouGov/Polimetrix for their help in fielding the surveys. 
responses among different population subgroups and why prior experimental and real-life studies come to conflicting conclusions. We argue that previous work misses a critical actor: the media. This happens even though the media, and television in particular, has been called the "most critical conduit" by which Americans learn about the Supreme Court's actions (Slotnick and Segal 1998, p. 231). In prior experimental studies, researchers assume the role of the media themselves and offer one-sided information about a major Court decision to all respondents (see Chong and Druckman 2007, pp. 638-39). Prior studies in natural settings, in contrast, often group respondents who were not exposed to any media coverage of the Court decision with those exposed to one- and two-sided coverage. We show that the intersection of the Court and the media matters critically for opinion change. The Supreme Court depends more heavily on the media to convey and translate its messages than do other elite actors. Elites in the executive and legislative branches often speak directly to the public; they also buy advertisements and hold frequent press conferences to ensure that their messages are spread widely. In contrast, the nine justices communicate their views through lengthy and complex judicial opinions. As a result, the media's role is distinctly important to the Court's influence on public opinion (Davis 1994, p. 16).

We hypothesize that the public tends to follow the Court's cues when two things occur: the Court rules on a politically salient issue and the national media present their audiences with one-sided coverage supportive of the Court decision. The media are especially likely to cover politically salient cases, as prior studies (for example, Slotnick and Segal 1998) and our data indicate. We expect some of this coverage to be one-sided and positive. We define one-sided positive coverage as messaging supportive of the Court majority; in contrast, two-sided coverage contains both supportive and critical information. Given the influence of elites' cues on public opinion (for example, Kuklinski and Hurley 1994), exposure to one-sided positive coverage of a trusted actor's views should cause some Americans to change their views, as prior experimental studies of framing effects show (for example, Nelson, Clawson, and Oxley 1997; Chong and Druckman 2007).

Three research design innovations allow us to test our theory and to add to the literature on how interactions between elites and the media shape public opinion more generally (for example, Iyengar et al. 1984; Page, Shapiro, and Dempsey 1987; Zaller 1992). First, we survey a nationally representative sample of Americans shortly before and shortly af- 
ter two major and surprising Court decisions on health care and immigration, asking people for their views on the individual-mandate provision of the Affordable Care Act (Pub L. No. 111-148, 124 Stat. 119) and the "show your papers" provision of Arizona's immigration law. Prior studies of Court decisions in real-life settings are based on survey questions fielded for other purposes, such as the General Social Survey, and thus share a major limitation: there is a very long time gap, often 1 year or more, between the before sample and the after sample, and events other than the Court decision could influence opinion in this interval (Hoekstra 1995, pp. 112). We are able to show short-term effects because of the proximity of our surveys to the Court rulings, and we document long-run effects by pairing our data with other surveys.

Second, we combine public opinion data with detailed media coverage data and connect individuals' opinion shifts with the content of television programs they watch. Scholars note that "most published work on media effects does not include measures of media content" (Barabas and Jerit 2009 , p. 74), and "most researchers fail to ascertain, let alone contentanalyze, the media information that, they assume, their subjects encountered" (Graber 2004, p. 516). Kinder (2007, p. 158) finds it "unnerving ... that we are still waiting for compelling demonstrations of framing effects in natural settings." Because the Supreme Court decisions we study received both widespread coverage and coverage that varied dramatically across television programs, we are able to document framing effects in a natural setting and show how Court decisions and media coverage interact to produce national opinion shifts.

Third, we combine our observational study with an experiment to better address selection effects, the key limitation of research in real-life settings. We find that Court decisions influence people who hear about them only through the media they normally use and increase overall support for policies the Court upholds as constitutional. These effects were largest among people who received one-sided information emphasizing the frame chosen by the Court majority. Two-sided coverage, in which a news program emphasizes both the Court majority's frame and alternative framings of the issue, did not confuse people about what the Court had held but did reduce the impact of the Court decision on opinion change. We also find that people who first heard about Court decisions through the media sources they normally use and people who first heard about Court decisions in the course of our experiment responded in similar ways. These findings contribute both to the literature on courts and 
to the literature on public opinion formation, as effects of elites and the media have mostly been studied separately until now.

Although the two cases in our study generated appreciable media attention, they share features that make them hard tests of our theory. In both cases, the Court offered only a weak endorsement of the provisions on which we focus, the show-your-papers provision and the individual health care mandate. Both cases had been extensively debated in the media in the months prior to the rulings. Moreover, the debate tended to follow partisan lines, with Democrats supporting the health care mandate and Republicans supporting the show-your-papers provision. Thus, many respondents likely had firm opinions on immigration and health care before the Court rulings. These features bolster the generalizability of our results, as we expect stronger Court endorsements of novel issues to generate larger public opinion shifts.

\section{HOW SUPREME COURT AND MEDIA CHOICES SHAPE NATIONAL OPINION}

We argue that the interactions between two actors-Supreme Court justices and the national media-explain when Court decisions lead national public opinion, persuading ordinary Americans to increase (decrease) their support for policies the Court declares constitutional (unconstitutional). Studies have demonstrated the ability of high-credibility elites to lead public opinion through a process of heuristics and cue taking (see, for example, the summary in Bartels and Mutz [2009, p. 251]). Because the Supreme Court has traditionally been the most trusted branch of the federal government (Caldeira and Gibson 1992), we expect that Court rulings have the potential to provide highly influential cues to the American public. For cue taking to occur, three conditions must hold. First, the Supreme Court must decide to review a politically salient issue. Second, journalists must give extensive and one-sided coverage to the decision. ${ }^{1}$ Third, many individuals must hear about and understand this news coverage, and some of these must change their views in accordance with the Court ruling.

1. One-sided positive coverage should move opinion in the direction of the Court ruling, while one-sided negative coverage should have the opposite effect. 


\subsection{Rulings on Politically Salient Issues and News Coverage}

Supreme Court justices can sharply reduce the probability that they will shape public opinion by refusing to take on politically salient issues. The Court has significant discretion over the cases it reviews and grants fewer than 1 percent of the petitions it receives. ${ }^{2}$ Prior work establishes that when the Court uses its discretion to deny review, limited news coverage typically follows, even on politically salient and controversial issues (Slotnick and Segal 1998). In turn, limited national coverage leaves national opinion unchanged (Hoekstra 2003).

Conversely, many cases taken on by the Supreme Court receive extensive coverage at the time of the Court ruling. Cases on politically salient topics, especially those involving individual rights, tend to receive disproportionately more media coverage relative to their share of the Court docket (for example, Solimine [1980]; Bowles and Bromley [1992]; see Persily, Metzger, and Morrison [2013] for a discussion of the importance of the Affordable Care Act ruling). In addition, cases that attract many amicus briefs and cases involving multiple dissents garner more coverage, as journalists often consider these important and controversial, and thus newsworthy (Sill, Metzgar, and Rouse 2013, p. 74). However, prior studies cannot tell us why some widely covered cases change Americans' views, while others do not, so we turn to this point next.

\subsection{One-Sided Frames and Americans' Views}

While extensive news coverage is necessary for Americans to become aware of a Court ruling, we argue that the nature of this coverage determines whether they will take cues from the ruling and update their opinions. More specifically, the arguments that justices develop to support their conclusions and journalists' choices about how to present, add to, or challenge the Court's argumentation are critical. To explain how lengthy and complex legal opinions are translated into short sound bites, we combine general theories about journalism with work specific to journalists covering the Supreme Court.

The Court is distinctive among elite actors in the United States, in that the public hears about its rulings only indirectly. After the Court issues its complex and lengthy opinions, the media decide how to translate those opinions to the public. In contrast, videos of members of Congress or

2. Supreme Court of the United States, Frequently Asked Questions (http://www .supremecourt.gov/faq.aspx). 
the president speaking are often aired on the news-there is less need for the media to translate what they say, because the public can hear these messages directly. This elevates the media's role to that of a critical mediator in studies of Court influence on public opinion (Davis 1994, p. 16; Franklin and Kosaki 1995). We focus on television coverage, as television remains the main source of news for most Americans, even in the digital era (Pew Research Center 2011), and, as we note above, is viewed as the "most critical conduit" for information about the Supreme Court (Slotnick and Segal 1998, p. 231). As reporters covering the Court seldom have the time to tell as many stories as they would like (Slotnick and Segal 1998, p. 47), media outlets will pick one or only a few frames likely to resonate with viewers.

Although there are three possible options for coverage-one-sided positive, two-sided, or one-sided negative-we expect that the media will typically choose either one-sided positive or two-sided coverage. Scholarship on journalists covering the Court suggests that they may understand their role as explaining, rather than criticizing, Supreme Court opinions (Slotnick and Segal 1998, p. 21; Davis 1994, p. 20). By reporting on the Court's actions through the frames chosen by the Court majority, journalists may end up presenting one-sided, largely uncritical coverage. Early studies suggest that television coverage mostly presents the Court majority's position and does not differ significantly among the networks (Katsh 1983; Davis 1987; Slotnick and Segal 1998).

A different theory of journalism, indexing theory, in turn suggests that journalists seek to avoid acting as mouthpieces for the administration and instead turn to diverse government elites and interest groups to construct frames: they index their reporting to the "magnitude and content of conflicts among key government decision-makers [and other powerful players]" (Bennett 1996, pp. 376-77). Because politicians and interest groups are eager to voice both supportive and critical viewpoints on controversial Court decisions, indexing theory leads us to expect two-sided coverage. We would thus expect to see either one-sided positive coverage or two-sided coverage rather than one-sided negative coverage. That said, it is possible that journalists working for partisan cable networks, namely, Fox News and MSNBC, consistently emphasize frames supportive of their networks' ideologies (Meader 2013) that could be entirely hostile to the Court, so it is important to study current coverage data. Such variations in media coverage could shape the persuasive effects of Court decisions, as we explain next. 


\subsection{Extensive One-Sided Media Coverage and Persuasion}

Journalists' choices about the frames they select, and the considerations they emphasize, should influence public responses to Court decisions. Many survey experiments indicate that individuals who receive onesided frames change their opinions accordingly, while individuals who receive two-sided, competing frames are more likely to retain their original views (for example, Druckman 2001; Chong and Druckman 2007, 2013). However, these experimental studies involve fictitious information transmitted to respondents by researchers; as we note above, Kinder (2007, p. 158) says that "we are still waiting for compelling demonstrations of framing effects in natural settings." If Supreme Court decisions receive both extensive coverage and a variety of one-sided and two-sided coverage, we should be able to identify framing effects following actual Supreme Court cases. By separating respondents who receive no information, one-sided information, or two-sided information from the media they regularly use, we should be able to reconcile experimental findings with real-life results.

Hypothesis 1. People who receive one-sided information supportive of the Court majority's ruling should respond more positively than people who receive two-sided information (that also includes critical frames), both in experiments and in natural settings.

\section{RESEARCH DESIGN}

Prior studies of the Supreme Court's influence in natural settings rely on data generated for other purposes, and long lags often separate the before and after waves. In contrast, the survey research firm YouGov fielded our two-wave, nationally representative survey shortly before and shortly after two major Court decisions. Survey respondents received the first wave of questions in May 2012, about 5 weeks prior to the rulings, and the second wave in the days after the rulings. For each survey, 1,300 respondents completed wave $1 ; 87.5$ percent of these individuals completed wave 2 of the health care survey, and 82.3 percent completed wave 2 of the immigration survey. YouGov reweighted these survey responses to create a nationally representative sample and provided us with complete responses for 2,000 subjects (1,000 per study).

We combined these public opinion data with news coverage data. Scholars note that most published work on media effects does not, in 
fact, record or analyze media coverage (Barabas and Jerit 2009, p. 74; Graber 2004, p. 516). The few prior on-point studies find that few Americans respond to events that receive limited national coverage (for example, Barabas and Jerit 2009; Jerit, Barabas, and Bolsen 2006; Nicholson 2003; Price and Czilli 1996), and only the opinions of highly attentive subgroups are likely to change in response to these events (Barabas and Jerit 2010).

By focusing on Supreme Court cases that received moderate to high levels of coverage, we can study how a broader cross section of Americans respond and examine whether factors besides the volume of coverage-such as the frames used by different news sources-influence opinion change. We analyze how six different television networks covered two major Supreme Court cases and connect individuals' opinion shifts to frames to which they were (or were not) exposed, to provide the first comprehensive study of framing effects in a natural setting. Section 4 outlines how we content analyzed news media coverage.

While studies in natural settings have important external-validity advantages and provide "more realistic news scenarios" than what experiments typically offer (Chong and Druckman 2011, p. 254), important concerns about selection arise. The best observational studies, for example, compare people who hear about an event with people who do not. But it is possible that avid news followers care deeply about political issues and current events and thus respond especially strongly to new information about political events. Similarly, we worry that that people who choose to watch Fox News tend to be conservative, or those who watch MSNBC tend to be liberal, and may be more likely than others to respond favorably to ideological messages.

To address selection concerns, we include careful controls, study changes in opinion (to account for individuals' views prior to the Court decision), and combine our observational study with an experiment. In this experiment, we randomly assigned people to receive different information about each case to see whether people who receive information through the media they choose and people randomly assigned to receive similar information respond in similar ways. For each study, 40 percent of respondents were randomly assigned to the no-reminder group $(n=$ 400) and did not receive any information about the content of the Court decision from us. The remaining respondents were divided into three equally sized groups and randomly assigned to receive different reminders about the decision ( $n=200$ per group). Our reminders drew on the 
major arguments developed by the justices. However, we presented our respondents with short summaries of key points, rather than extensive legal opinions, in an effort to make the information offered through the experiment comparable to the information a respondent might receive through the media she typically uses.

In sum, we expect that people who receive one-sided information that the Supreme Court has judged a law to be constitutional should increase their support for the law, whether they receive the information from the media they regularly use or from a researcher. In contrast, people who receive two-sided information should respond less positively; indeed, the net effect might be zero or even negative, depending on the relative strength of the competing frames. We also expect that when information is repeated in the course of an experiment to people who have already received it through the media they regularly use, we should not see a further response (Druckman and Leeper 2012, p. 889). Table 1 outlines these predictions.

We expect two-sided frames to have smaller effects than one-sided frames; these attenuated effects could be zero if the two frames are equally strong or even negative if the counterframe is stronger than the main frame. Details about our question wording and study design and our robustness checks are in the online appendix.

\section{MEDIA COVERAGE OF THE HEALTH CARE AND IMMIGRATION DECISIONS}

Our goal is to examine whether variation in the frames that television programs use influence Americans' responses to Court decisions. In this section, we describe how the news media covered the health care and immigration decisions and provide evidence that media coverage of these decisions varied, with some news programs offering one-sided positive coverage and others offering two-sided coverage.

That said, there are some prerequisites to national opinion change: we expect to see national opinion shifts only when an event receives at least moderately high levels of and moderately clear news coverage. The immigration ruling received a moderately high level of news coverage, while the health care ruling received a high level of news coverage. In fact, media coverage of both health care and immigration issues spiked after the Supreme Court decisions to levels not seen before or since; no other actor or event, including the presidential debates, focused as much media attention on these issues as the Supreme Court. While both rulings 
Table 1. Theoretical Predictions

\begin{tabular}{llll}
\hline & \multicolumn{3}{c}{ Exposure from News Media } \\
\cline { 2 - 4 } Exposure from Experiment & \multicolumn{1}{c}{$\begin{array}{c}\text { No } \\
\text { Information }\end{array}$} & $\begin{array}{c}\text { One-Sided } \\
\text { Information }\end{array}$ & $\begin{array}{c}\text { Two-Sided } \\
\text { Information }\end{array}$ \\
\hline No information & No effect & Positive effect & Attenuated effect \\
One-sided information & $\begin{array}{l}\text { Positive effect } \\
\text { Two-sided information }\end{array}$ & $\begin{array}{l}\text { Positive effect } \\
\text { Attenuated effect }\end{array}$ & $\begin{array}{c}\text { Attenuated effect } \\
\text { Attenuated effect }\end{array}$ \\
\hline
\end{tabular}

received moderate-to-high levels of attention, coverage of the health care case was more straightforward than coverage of the immigration case. Every major TV evening news program said that the health care law had been upheld, while in the case of the immigration decision, some TV programs said that the law had been upheld, others said that the law had been struck down, and still others suggested that it was a mixed decision. ${ }^{3}$ Some Americans may have therefore misunderstood the Court ruling, and we take care to identify them.

Figures 1 and 2 show the frames used by evening news programs in covering each decision. Two students coded the evening news transcripts following the procedures outlined in Chong and Druckman (2011), coding for both valence and framing. Six frames were identified for each case; these were derived from the transcripts from morning, afternoon, and late-night news. The bars in Figures 1 and 2 represent the amount of time devoted to each frame as a percentage of total time devoted to the six frames. ${ }^{4}$ Our coders counted the total number of positive, negative, and neutral words belonging to each of the six frames. ${ }^{5}$ We used these

3. While the Court unanimously upheld the controversial show-your-papers provision, it was divided along partisan lines in striking down three other provisions. See the online appendix for more on the news coverage.

4. General news coverage that did not fit into any particular frame took up approximately half of each evening news program. Although the percentages in Figures 1 and 2 change when the denominator becomes total words, rather than words devoted to any frame, the relative amounts of positive, mixed, and negative coverage remain the same.

5. Coders were first trained using transcripts from news programs not airing in the evening. They then evaluated the evening news transcripts, sentence by sentence, classifying each sentence, or portion thereof, in two ways: the valence of the text and the frame it evoked. Valences were either positive (supportive of the Court ruling), negative (opposed to the Court ruling), or neutral (a sentence that is neither, such as "Majority Leader Harry Reid spoke about the ruling today"). Coders were provided with the six frames-previously identified using the morning, afternoon, and late-night news about the rulings - and asked to determine whether the sentence fit one of the six frames or could be classified as general commentary (for example, "The Court ruled today on Arizona's immigration law"). Our coders then totaled the number of positive, negative, and neutral words belonging to each of the six frames for all transcripts. 


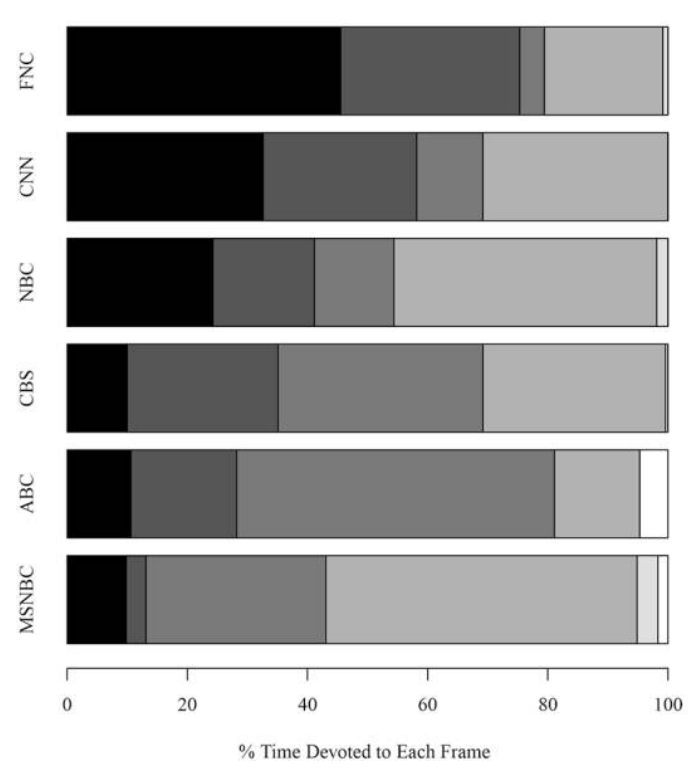

- Taxes (Negative)

Government overreach (Negative)

$\square$ Uninsured (Positive)

$\square$ Court partisanship (Positive)

$\square$ Health care as a right (Positive)

Quality of care (Positive)

Figure 1. Frames used by six evening news shows in coverage of the health care ruling

totals to determine whether frames were used in a consistently positive or negative way by the six networks or whether usage was mixed. ${ }^{6}$

In the health care case, four frames were consistently used in a positive way, supportive of the Court majority. These included frames presenting health care as a basic right, changes in quality of care, impact on the uninsured, and the argument that the decision on the mandate overcame

6. We summed the total number of positive and negative words identified by our coders for each frame across the six news programs and then calculated the percentage of positive words used (for example, positive words used in racial profiling frame/positive + negative words used in racial profiling frame). If this percentage exceeded 75 percent, we classified the frame as used by the six evening news networks in a positive way, and if it fell below 25 percent, we classified the frame as being used in a negative way. Percentages between 25 and 75 percent were classified as mixed. We followed the procedure used in Chong and Druckman (2011) to determine whether our coders agreed about the presence of frames in a given transcript. We found 93.1 percent agreement about presence (or near total absence) of frames and a Krippendorf's alpha of .85. This measure takes a more conservative estimate of intercoder reliability, allowing some agreement by chance. As we were interested in the amount of negative coverage in each transcript, we also determined the intercoder agreement about the percentage of negative frames, again following Chong and Druckman (2011). Our alpha for the percentage of negative frames in each transcript was .94. These results meet and perhaps exceed typical standards of intercoder reliability. See the online appendix for additional details about the coding process and robustness checks; our results are consistent when we use alternative coding rules. 


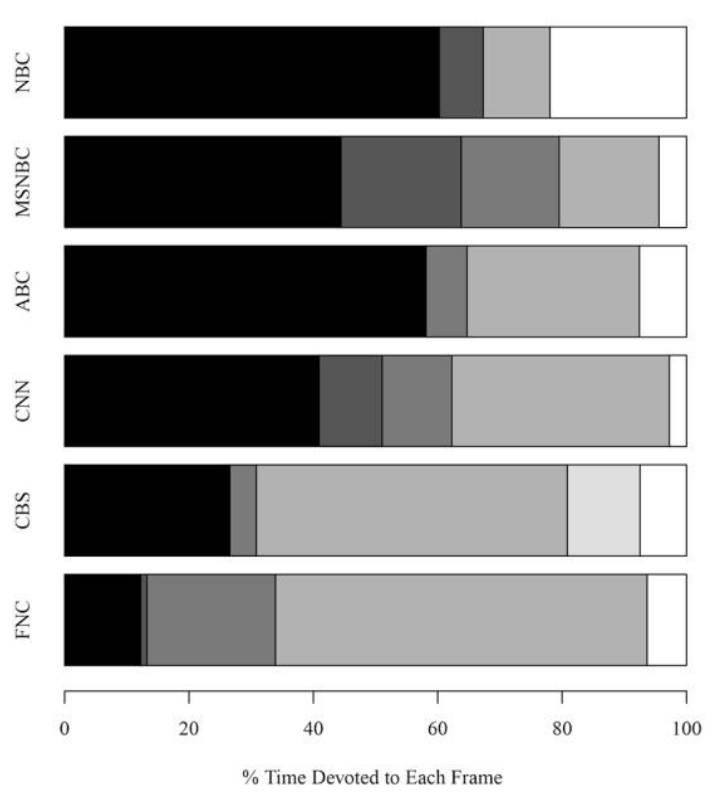

- Racial profiling (Negative)

$\square$ Federalism (Mixed)

Crime (Positive)

Border security (Positive)

Figure 2. Frames used by six evening news shows in coverage of the immigration ruling

traditional partisanship on the Court (as conservative Chief Justice John Roberts sided with the liberal justices). Two frames, concerning taxes and government overreach, were used in a consistently negative manner. In the immigration case, two frames were used in a consistently positive way: news programs argued that the immigration law could help with both crime and border-security issues in Arizona. Two frames were used in a consistently negative way, raising concerns about racial profiling and about Court partisanship. Two additional frames, concerning federalism and immigration reform, were not used consistently and are thus coded as mixed.

On the basis of prior studies of television networks' partisan leanings and viewers' ideological news preferences (for example, Groeling 2008; Iyengar and Hahn 2009), we would expect to see more conservative coverage on Fox News, more liberal coverage on MSNBC, and relatively centrist coverage on ABC, CBS, NBC, and CNN. Perhaps unsurprisingly, our coding suggests that in the health care case, which upheld a provision championed by Democrats, Fox News allocated the most time to negative frames (frames critical of the Court majority), and MSNBC allocated the least. Conversely, in the immigration case, which upheld a provision 
championed by Republicans, Fox News allocated the least time to negative frames, and MSNBC allocated the second-highest amount of time.

What is more surprising to us, however, was that the partisan networks-although critical of decisions that went against their ideological leaning (Fox News on health care and MSNBC on immigration)-explained the rulings in detail and featured some ideologically opposed arguments (for example, benefits for the uninsured on Fox News and aid for border security on MSNBC). Our data suggest that even when a partisan network encounters a Court decision that runs strongly counter to its ideology, it does not devote all of its time to criticisms of the Court. In contrast, when decisions were consistent with the ideology of these partisan networks, the networks opted to present positive one-sided coverage and raise very few competing considerations. Many nonpartisan networks also chose one-sided positive coverage, presenting the Court majority's argument alongside predominantly supportive arguments from other actors.

Our data thus provide tentative support for the second part of our theory, the argument that journalists tend to offer one-sided positive or two-sided coverage of Court decisions. This support is only tentative, because it is based on two Supreme Court cases rather than the universe of cases. Yet prior work suggests that many Court cases are reported in the media as straightforward accounts of what the Court decided and the rationale it provided for its own actions (Davis 1994, p. 20; Spill and Oxley 2003, p. 24). Because the two cases we studied are high profile and controversial, with the controversy closely following partisan lines, it is especially surprising that we do not see exclusively critical coverage.

Extensive and straightforward coverage of the health care decision led 70 percent of our respondents to correctly state that the Court had upheld the individual mandate and 6 percent to state (incorrectly) that the law had been struck down, while another 25 percent did not know. In contrast, the more limited and confusing coverage of the immigration decision led 46 percent of our respondents to correctly note that the Court had upheld the show-your-papers provision and 14 percent to state (incorrectly) that it had been struck down, while another 40 percent did not know which way the Court had ruled. Further analysis of the data suggests that there exists a simple linear relationship between the fraction of the evening news hour devoted to the case and viewers' understanding of the case. That is, even though viewers of Fox News received critical coverage of the health care decision, while viewers of MSNBC received cov- 
erage that was much more supportive of the Court majority, this did not seem to confuse respondents; viewers of both stations' evening news programs were very likely to correctly understand the ruling simply because they were exposed to extensive information about it. This finding contributes to a new literature on the effects of partisan media that suggests that simplification along ideological lines may help some viewers process complex political messages (Stroud 2011, pp. 9-10, 108).

That said, closer analysis of our data identifies an important limitation of our measure of knowledge of each case. People who correctly stated that each law had been upheld were disproportionately likely to have supported the law prior to the Court decision in wave 1 of our survey. This effect is particularly pronounced in the immigration case. We believe that a fraction of our respondents interpreted the news coverage they saw in accordance with their prior beliefs; the confusing news coverage of the immigration case magnified this tendency. As a result, we use a measure of exposure rather than one of awareness, as Section 5 explains.

In sum, analysis of news media coverage suggests that both decisions received extensive coverage, much of which was clear, and as a result, large numbers of Americans' understood the Court's ruling. We also observe that television news programs offered one-sided positive coverage or two-sided coverage of each decision and that even ideologically opposed networks devoted time to explanation and frames supportive of the ruling. Whether and how this coverage contributed to opinion change is the question we take up next.

\section{NATIONAL PUBLIC OPINION FOLLOWING COURT RULINGS}

\subsection{Court Decisions in Natural Settings}

In the observational portion of our study, we find that support for the health care and immigration provisions we studied increased after the Supreme Court upheld them. We also find that people exposed to one-sided frames (which drew on and supported the majority opinion) through the media they typically use responded more positively to the Court decision than people exposed to two-sided frames (which also emphasized the dissent, or arguments against the ruling).

We first examine aggregate support for the individual mandate over time (Figure 3). Our survey data show that, among people who received no experimental reminder, support for the individual mandate increased 


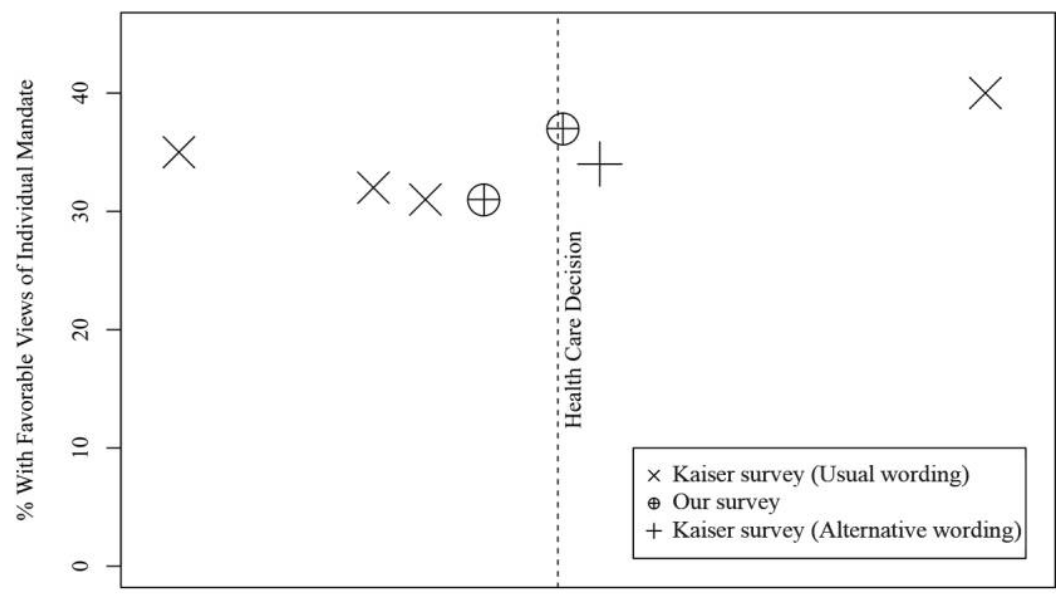

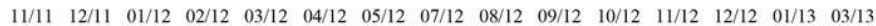

Date of Survey

Figure 3. Support for the individual mandate over time

from 29 percent before the decision, in mid-May 2012, to 35 percent in the days after the decision, in late June $2012(p<.05)$. We tried to field our surveys as close to the Court decision as possible so that our beforeand-after comparison reflects responses to the Court decision rather than responses to other intervening events.

We complement our data with data collected by the Kaiser Family Foundation (2013) to illustrate that our short-term effects persisted for many months after the decision. Although the Kaiser Family Foundation used a different sampling technique and phrased its questions differently than we did, it is reassuring to see that its findings are very similar to ours. More specifically, the Kaiser surveys suggest that support for the individual mandate increased from 32 percent in March 2012 to 40 percent in March 2013 and thus that the short-term bump we report persisted for many months after the Court decision. In addition, the Kaiser survey suggests that there was no upward trend in support for the mandate in the months preceding the Court decision, which helps reassure us that the decision constituted a turning point. ${ }^{7}$

We see a bump in support for the show-your-papers provision in our data following the immigration decision, which upheld this provision of

7. Kaiser used distinctive question wording in the survey immediately after the ruling (July 2012), marked with a cross in our graph. 
Arizona's immigration law, but it is small and not statistically significant. The discrepancy may well be because coverage of the immigration decision was more limited and confusing than coverage of the health care decision. As a result, only a minority of Americans understood that the Court had upheld the controversial show-your-papers provision, while others did not know, and still others believed that the provision had been struck down.

It is, therefore, important to not only measure aggregate opinion change but distinguish people who heard and understood the decisions from those who did not. Current best practice suggests that questions about exposure to news coverage, rather than questions about knowledge of the content of the news coverage, should be used to distinguish treated from untreated subjects (Druckman and Leeper 2012). Had we used questions measuring knowledge-such as those in our survey asking people whether the provision had been upheld or struck down-as a measure of treatment, we may have introduced bias, because respondents can use their prior beliefs to make sense of news coverage. Severe bias is particularly likely when news coverage is confusing, as in the immigration study. For example, people who strongly supported the show-your-papers provision in wave 1 were far more likely to (correctly) indicate that it had been upheld, relative to people who opposed the provision in wave 1 .

While prior studies highlight that exposure, rather than knowledge, is the correct way to distinguish treated from untreated respondents, there is limited research on which measures of exposure are best. Indeed, some of the best prior work is concerned with only whether someone was exposed to a particular media source, rather than to news of a specific event, and thus a simple binary measure of exposure is appropriate (for example, DellaVigna and Kaplan 2007; Gerber, Karlan, and Bergan 2009).

Because we are interested in exposure to specific events, and in general exposure to a news source, we had to construct new measures of exposure. As this part of the coding is novel and somewhat subjective, we present four exposure cutoffs so as to be as transparent as possible about how our coding of exposure influences our results. The health care decision received widespread and straightforward coverage, while the immigration decision received moderate and somewhat confusing coverage. ${ }^{8}$

8. For theoretical reasons, we believe that it is appropriate to use a high threshold of exposure for the health care decision and a moderate threshold of exposure for the immigration decision. We show all thresholds for both decisions in the interest of transparency. 
The measures of exposure we present come from a question in our survey that asked respondents to indicate whether they had heard about a series of seven prominent news stories around the time of the decisions. We asked respondents how many of the following headlines they had seen: one about the Court ruling plus six drawn from other events in the news at that time (the Egyptian elections, a Mitt Romney donor retreat, Dick Cheney's daughter's wedding, a Red Sox trade, the Jerry Sandusky trial, and the departure of a Today show host). ${ }^{9}$ By combining the headlines respondents indicated having seen in various ways, we were able to identify two relatively low thresholds of exposure (the most attentive 90 percent and 75 percent of our sample) and two moderate-to-high thresholds (the most attentive 25 percent and 35 percent of our sample) to divide people who were likely to know about the Court ruling prior to our experiment - the treated group-from those who were not. ${ }^{10}$ Using other questions about attentiveness to politics, we constructed alternative thresholds as well, and we present these robustness checks in the online appendix.

The health care case received widespread and straightforward coverage, so we believe that the first two thresholds (separating out the most attentive 90 and 75 percent of the population) best distinguish people who likely heard and understood this decision from people who did not. In contrast, because the immigration decision received moderate and somewhat confusing coverage, we believe that the second two thresholds (separating out the most attentive 35 and 25 percent of the population) are more appropriate. As a robustness check, we analyze opinions for both cases using each of the four cutoffs.

Because our research examines whether people changed their minds following the Court decisions, our dependent variable takes on three values: 1 for an increase of support for the provision from wave 1 to wave 2, 0 for no change, and -1 for a decrease in support. As the Court upheld

9. The headline about the Supreme Court in our question did not include information about the direction or content of the decision.

10. Using the question about exposure to headlines, we arrived at these thresholds as follows. About 90 percent of our sample had seen at least one of the seven headlines, so we classified these respondents as the most attentive 90 percent. Similarly, about 75 percent of the sample indicated that they had seen the headline about the Court, about 35 percent of the sample indicated seeing at least five of the seven total headlines, and about 25 percent of the sample saw the three political headlines. These four options, we felt, represented four realistic ways of distinguishing those who were likely to have been exposed to information from the Court from those who were likely to not have been exposed to this information prior to our study. 
Table 2. Health Care Opinion Change by Type of News Media Exposure

\begin{tabular}{lccc}
\hline Treatment Cutoff & $\begin{array}{c}\text { Overall } \\
\text { Effect }\end{array}$ & $\begin{array}{c}\text { One-Sided } \\
\text { Information }\end{array}$ & $\begin{array}{c}\text { Two-Sided } \\
\text { Information }\end{array}$ \\
\hline Main specifications: & & & \\
Most attentive 90\% & $.37^{* *}$ & $.41^{* *}$ & $.28^{+}$ \\
& $(.13)$ & $(.13)$ & $(.14)$ \\
Most attentive 75\% & $.13^{+}$ & $.19^{*}$ & .03 \\
& $(.08)$ & $(.08)$ & $(.09)$ \\
Robustness checks: & & & $.16^{+}$ \\
Most attentive 35\% & .10 & $(.08)$ & .01 \\
Most attentive 25\% & $.20^{* *}$ & $.30^{* *}$ & .07 \\
& $(.07)$ & $(.09)$ & $(.07)$ \\
\hline
\end{tabular}

Note. The subjects received no experimental reminder. Standard errors are in parentheses. $N=400$.

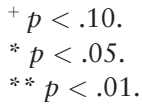

both laws, a 1 can also be interpreted as a shift toward the Court ruling, while $a-1$ can be interpreted as a shift away from the Court ruling. This coding follows earlier studies (for example, Egan and Citrin 2011), allowing for comparability. A shift toward the Court ruling (a score of 1) includes people who move from strong disagreement with each provision to mild disagreement, to neutrality, or to support. Thus, we capture more movement than if we study only people who move from opposing to supporting each provision (and vice versa).

Table 2 examines the 400 individuals in the study of the Affordable Care Act who received no reminder from us and heard about the case only from the news media they regularly use. To determine the overall effect, we estimated four ordinary least squares (OLS) models. All models include the same control variables (partisanship, race, education, marital status, employment status, and gender), but each uses a different cutoff value to separate the treated group from the control group.

Results for the overall effect show that however we define the treated group, people who heard about the case were more likely to increase their support for the individual mandate than people who had not. This difference is generally, but not always, statistically significant. However, the magnitude of the effect varies across specifications. When we set lower thresholds for knowledge, we find larger effects. Because coverage of the 
decision on the Affordable Care Act was widespread and straightforward across news media outlets, we believe that lower thresholds more accurately capture the true effect of the case; the high thresholds likely include in the control group many people who had heard about the case, which biases our estimates of the treatment effect downward.

We next wanted to compare people who received one-sided coverage of the health care decision from the media they regularly use with people who received two-sided coverage. Figure 1 suggests that over 65 percent of the analysis on Fox News, CNN, and NBC used frames that were critical of the Court majority. Thus, we define viewers of these programs as being exposed to two-sided coverage and viewers of other programs as being exposed to one-sided coverage. Results are very similar when we use other thresholds for one-sided versus two-sided coverage (see the online appendix). We reestimated our OLS models, using two treatment dummies (attentive people who received one-sided coverage and attentive people who received two-sided coverage) and the control variables mentioned above. As shown in Table 2, in every model, people who received one-sided coverage were more likely to increase their support for the mandate than people who received two-sided coverage $(p<.01)$. This provides clear evidence of real-world framing effects. Consistent with our expectations in Table 1, one-sided coverage produces larger effects than does two-sided coverage.

Table 3 repeats this analysis for the 400 people who received no reminder from us in the immigration study. We estimate the same models as for Table 2. Again, we find that for all treatment thresholds, attentive people were more likely to increase their support for the show-yourpapers provision that the Court upheld, although the difference is not always statistically significant. Because coverage of the immigration decision was less widespread and more confusing than coverage of the health care decision, we believe that a higher threshold (separating out the most informed 35 or 25 percent) for differentiating treated and untreated people is appropriate. The lower thresholds likely include too many people in the treated group who did not understand that the Court had upheld the show-your-papers provision. As with Table 2, we find a larger effect among people who received one-sided coverage from the news media they normally watch than among people who received two-sided coverage.

In the study of the immigration decision, however, the differences between the one- and two-sided groups are not always statistically significant. It is possible that the main negative frame used in the health care 
Table 3. Immigration Opinion Change by Type of News Media Exposure

\begin{tabular}{|c|c|c|c|}
\hline Treatment Cutoff & $\begin{array}{l}\text { Overall } \\
\text { Effect }\end{array}$ & $\begin{array}{l}\text { One-Sided } \\
\text { Information }\end{array}$ & $\begin{array}{l}\text { Two-Sided } \\
\text { Information }\end{array}$ \\
\hline \multicolumn{4}{|l|}{ Robustness checks: } \\
\hline Most attentive $90 \%$ & $\begin{array}{l}.07 \\
(.09)\end{array}$ & $\begin{array}{l}.10 \\
(.09)\end{array}$ & $\begin{array}{l}.00 \\
(.11)\end{array}$ \\
\hline Most attentive $75 \%$ & $\begin{array}{l}.17^{*} \\
(.08)\end{array}$ & $\begin{array}{l}.19^{*} \\
(.08)\end{array}$ & $\begin{array}{l}.12 \\
(.10)\end{array}$ \\
\hline \multicolumn{4}{|l|}{ Main specifications: } \\
\hline Most attentive $35 \%$ & $\begin{array}{l}.11 \\
(.07)\end{array}$ & $\begin{array}{l}.17^{*} \\
(.07)\end{array}$ & $\begin{array}{l}.02 \\
(.10)\end{array}$ \\
\hline Most attentive $25 \%$ & $\begin{array}{l}.14 * \\
(.07)\end{array}$ & $\begin{array}{l}.16^{*} \\
(.08)\end{array}$ & $\begin{array}{l}.10 \\
(.11)\end{array}$ \\
\hline
\end{tabular}

Note. The subjects received no experimental reminder. Standard errors are in parentheses. $N=400$.

$* p<.05$.

coverage (concerning an increase in taxes) resonated with a broad segment of the population, which resulted in fewer people exposed to twosided news increasing their support for the individual mandate. The main negative frame used in the immigration case, which concerned racial profiling, may have resonated with a narrower segment of the population. In short, both the presence and the strength of competing frames likely influenced the results, and more research is needed on this point.

The biggest concern with studies in natural settings generally, and thus with the above results, is that people self-select into news viewership. One of these concerns might be that people who choose to watch a partisan channel-such as Fox News or MSNBC—have particularly stable views. While we can never fully dismiss these concerns, we are confident that we are not merely reporting the results of respondents' media self-selection. For selection effects to bias results in favor of our findings, it would not be enough to have partisan respondents self-select into partisan networks or be more difficult to persuade. It would also have to be true that partisan networks present mostly two-sided coverage, which would result in hard-to-persuade respondents (partisans) being exposed to more mild stimuli (the two-sided news coverage). We found, through our analysis of the media coverage, that partisan networks are likely to present strongly one-sided coverage in favor of Court rulings with which they agree and two-sided coverage of rulings with which they disagree. Thus, for each case, we have one partisan network giving one-sided positive coverage 
(MSNBC on health care and Fox News on immigration) and one giving two-sided coverage that includes criticisms of the Court ruling (MSNBC on immigration and Fox News on health care). In both cases, we see that people exposed to one-sided frames respond more positively than people exposed to two-sided frames, and it seems unlikely that selection effects can account for both of these results. Our experiment, described below, helps us better handle a broad range of selection concerns.

\subsection{Experimental Reminders}

We combine our observational study with an experimental one to better address selection concerns and understand why the results of prior observational and experimental studies often differ. Our main finding is encouraging to experimentalists: people who first hear about an event in the course of an experiment and people who first hear about it from the news media they regularly use respond in similar ways. However, among people who had already received information from the media, mere repetition of this information did not further change their attitudes, though the addition of other information did.

Our main goal in this section is to compare how different treatments and combinations of treatments influenced attitude change. People could receive no information, one-sided information, or two-sided information from the media they normally use. Each of these groups could also receive no information, one-sided information, or two-sided information in the course of the experiment. We classify respondents into nine categories, as illustrated in Tables 1,4 , and 5.11

We then estimated an OLS model with eight dummy variables, one for each of the possible treatment combinations (real-world exposure and experimental exposure). The baseline omitted category is the group that received information neither from the media nor from the experiment. We array the coefficients on these various treatment groups in Table 4 to facilitate comparisons across rows and columns. ${ }^{12}$ This model includes the same control variables as before (partisanship, race, education, marital status, employment status, and gender); our results are robust to al-

11. We pooled the two one-sided experimental reminders, reminder 1 , which stated the Court's holding, and reminder 2, which also offered an argument in favor of the Court majority's holding.

12. For more details on the coding used in Tables 4 and 5, the full models, and robustness checks, see the online appendix. 
Table 4. Health Care Decision Study: Opinion Change by Exposure

\begin{tabular}{|c|c|c|c|}
\hline \multirow[b]{2}{*}{ Exposure from Experiment } & \multicolumn{3}{|c|}{ Exposure from News Media } \\
\hline & $\begin{array}{c}\text { No } \\
\text { Information }\end{array}$ & $\begin{array}{l}\text { One-Sided } \\
\text { Information }\end{array}$ & $\begin{array}{l}\text { Two-Sided } \\
\text { Information }\end{array}$ \\
\hline No information & & $\begin{array}{l}.43 * * \\
(.14)\end{array}$ & $\begin{array}{l}.32 * \\
(.14)\end{array}$ \\
\hline One-sided information & $\begin{array}{l}.32 * \\
(.14)\end{array}$ & $\begin{array}{l}.34 * \\
(.14)\end{array}$ & $\begin{array}{l}.39 * * \\
(.14)\end{array}$ \\
\hline Two-sided information & $\begin{array}{l}.01 \\
(.21)\end{array}$ & $\begin{array}{l}.25^{+} \\
(.15)\end{array}$ & $\begin{array}{l}.32 * \\
(.14)\end{array}$ \\
\hline
\end{tabular}

Note. Standard errors are in parentheses. $N=1,000$.

$* p<.05$.

$* * p<.01$.

ternative specifications, including other levels of the treatment threshold, ordered logit models, and models with additional control variables.

We first examine the role of the media in leading opinion change and see that how the media covers the Court matters. Table 4 shows that people who received only two-sided real-world reminders responded less positively to the ruling than people who received one-sided reminders from the media they regularly use $(p=.07)$. Similarly, people who received only two-sided experimental reminders were less likely to change their opinion than were people who received only one-sided experimental reminders, although this result is just beyond the threshold for statistical significance. ${ }^{13}$

We can, additionally, compare the effects on changes in opinion from exposure to real-world news and from our experiment, as well as whether repetition of information can have an effect on opinions. We see that people who received one-sided reminders from the media they regularly use responded in similar ways to people who did not follow the news but did receive one-sided reminders from us; these coefficients are somewhat similar in size. This is reassuring to experimentalists, as it helps reject the idea that people who do not follow the news in the real world would be indifferent to the news if, in fact, they were exposed to it.

13. We find that people who received two-sided experimental reminders were less likely to change their opinion than people who received real-world two-sided reminders. This discrepancy could be due to the fact that our experimental reminder was delivered shortly before people answered the question about a change in opinion, which made the competing message more salient in the experiment than it would have been in the real world. 
Table 5. Immigration Decision Study: Opinion Change by Exposure

\begin{tabular}{lccc}
\hline & \multicolumn{3}{c}{ Exposure from News Media } \\
\cline { 2 - 4 } Exposure from Experiment & $\begin{array}{c}\text { No } \\
\text { Information }\end{array}$ & $\begin{array}{c}\text { One-Sided } \\
\text { Information }\end{array}$ & $\begin{array}{c}\text { Two-Sided } \\
\text { Information }\end{array}$ \\
\hline No information & & $.17^{*}$ & .03 \\
One-sided information & $.11^{*}$ & $.07)$ & $(.09)$ \\
& $(.05)$ & $.19^{* *}$ & $.22^{* *}$ \\
Two-sided information & .12 & $.23^{* *}$ & $(.09)$ \\
& $(.07)$ & $(.09)$ & $.28^{*}$ \\
& & & $(.14)$ \\
\hline
\end{tabular}

Note. Standard errors are in parentheses. $N=1,000$.

$* p<.05$.

$* * p<.01$.

When we examine the results for people who received information both from the real world and from the experiment, we find that repetition of the message does not alter results, but the addition of a different message does. If we consider the group that received one-sided real-world information, there is no significant difference in opinions among the group that received no information from our experiment and the group that received a repeated, one-sided message-repetition did not further increase their support. However, for the group that received two-sided information from us-information that was new to them-support for the mandate decreased relative to those who did not receive additional information from us $(p=.07)$. These patterns, too, are reassuring for experimentalists, as they suggest true information effects at work.

Table 5 presents the results from our immigration study. Again, we first consider the effect of media coverage and then consider differences between real-world and experimental information. As with the health care study, we estimate an OLS model with eight dummy variables for the various treatments people could have received and our standard set of control variables; alternative models (different treatment thresholds, additional control variables, and ordered logit models) yield similar results. The results from the immigration study are very similar to those of our health care study.

We do not see significant differences in opinion change between people exposed to one- versus two-sided coverage, as we did in the health care case, and we believe that the most likely explanation is the lack of dissent (and presence of a concurrence) in the immigration case. Compet- 
ing considerations presented in the context of a nuanced majority opinion may work differently than competing considerations presented in the context of a dissent. Prior research suggests that competing considerations in a majority opinion can sometimes increase, rather than reduce, the persuasive appeal of the majority opinion (Simon and Scurich 2011).

It is also possible, for the individuals who received information from our experiment, that we see evidence of learning rather than repetition. Our experimental reminders were much clearer than much of the news coverage, and reminders 2 and 3 contained information that the showyour-papers provision was unanimously upheld, information that even highly informed respondents were unlikely to have obtained from the media they regularly use. As with the health care study, we find that people who first heard about the case from the experiment respond in ways very similar to those of people who first heard about the case from the media they regularly use. ${ }^{14}$

\section{CONCLUSIONS AND IMPLICATIONS}

We find that the American public takes cues from the Supreme Court, which can result in increased support for controversial laws that have been upheld by the Court. We also find that people who first hear about a decision through the media they regularly use and people who first hear about a decision in the course of an experiment respond in similar ways. However, the ability of Supreme Court rulings to change public opinion depends critically on how the media choose to frame a decision. When the media (or researchers) emphasize frames supportive of the Court majority, the influence of the Court is typically greater than when the media (or researchers) emphasize competing frames. We also find that people who heard from the media that a law had been upheld did not further increase their support for the law when this information was repeated in the course of an experiment.

Our findings differ from the conclusions of prior studies in real-world settings in two main ways. First, we show a modest population-wide increase in support for laws the Supreme Court upholds, whereas prior real-world studies show a null net effect. This difference results, in part,

14. There are no statistically significant differences in opinions between the group hearing only one-sided information from the media and the group hearing only one-sided information from us nor between the group hearing only two-sided information from the media and the group hearing only two-sided information from us. 
from our ability to isolate the effect of the Court decision using a short (6-week) window before and after the decision. In contrast, prior studies use a much larger window, of 1 year or more, and thus report on the combined effect of events that preceded and followed the Court decision. The short-term increase in support for the health care law persisted for many months, likely because there was no extensive countermobilization of the type that followed some earlier Supreme Court cases (for example, cases on abortion). Studying a variety of cases is critical, however, because media coverage of Court cases can be idiosyncratic. For example, news coverage of Roe $v$. Wade (410 U.S. 113 [1973]), perhaps the most studied Supreme Court decision, was unusually limited because President Lyndon Johnson died suddenly that day.

Second, we show a large increase in support for laws the Court upholds among people receiving one-sided coverage of the Court decision from the media they regularly use. To our knowledge, this is the first observational study that combines messages from elites and the media in this way and that documents framing effects in a natural setting by connecting individuals' shifts in opinions to the news coverage they received.

This research has significant implications for the literature on the US Supreme Court and for debates on the role of an unelected judiciary in democratic politics more generally. The Court is in an unusual position to focus national attention on particular issues. Whereas much of the news cycle is determined by events out of any individual leader's control, the power of the Court to draw attention to particular issues is especially noteworthy because it has broad discretion in picking the cases that it reviews. We find that the Court can lead public opinion, even on issues that have been extensively debated prior to its decisions and even when the decisions offer only a weak endorsement of controversial policies.

Although the two cases we study generated substantial media coverage, we expect to see similar, if not larger, movement of national opinion following high-profile Court decisions. This is because the cases we study involved a weak endorsement from the Court majority for policies that had been extensively debated along partisan lines before the rulings and on which many respondents already had firm views. Indeed, consistent with our claim that the Supreme Court can lead public opinion, recent polls suggest that support for same-sex marriage reached an all-time high following favorable Supreme Court decisions on this issue in 2013 (Saad 
2013). ${ }^{15}$ These findings lead us to believe, contrary to the prior observational literature, that the Court offers more than a hollow hope for advocates of social change (Saad 2013). Instead, consistent with constitutional dialogue theory, we find that Court decisions in support of controversial laws increase support for these laws, and this might help quell questions about the normative legitimacy of an unelected judiciary (Ackerman 1991; Kramer 2004).

However, the nature of a Court decision and the way in which it is transmitted through the media moderates the response of the public. Our data suggest that national media seem to treat the Supreme Court with greater deference than they treat the other branches of the federal government and are often willing to offer primarily one-sided coverage supportive of the Court majority. In turn, people who receive this one-sided coverage from the media respond much more positively than people who receive two-sided coverage (with countervailing frames drawn from the dissent or from other sources). That said, the way in which a decision is written might modify its impact. It is possible that countervailing considerations introduced in the context of a dissent reduce the influence of the Court more than countervailing considerations introduced in the context of a nuanced majority opinion or concurrence. Future research along these lines would be very fruitful.

Although the public takes cues from Supreme Court rulings, it may not be the goal of the Court, generally, or the justices, individually, to change public opinion. Upholding a policy as constitutional does not necessarily imply that justices believe that it is the best policy. Indeed, in his opinion for National Federation of Independent Business v. Sebelius (132 S. Ct. 603 [2011], p. 6), Chief Justice Roberts suggests that the mandate may be constitutional but may not be good policy: "Members of this Court are vested with the authority to interpret the law; we possess neither the expertise nor the prerogative to make policy judgments. ... It is not our job to protect the people from the consequences of their political choices." In short, popular reactions to Supreme Court decisions may not correspond with Supreme Court justices' political goals.

We have strong theoretical reasons to believe, first, that the combination of elites' messages and the media coverage of these messages matters greatly and, second, that the Court-media interaction is distinct from the

15. However, it is somewhat more difficult to draw causal inferences from this poll data than from the poll data on health care analyzed here, because support for same-sex marriage had been on an upward trend long before the Court decision, whereas support for the individual mandate was stable or possibly declining. 
executive-media or legislature-media interaction. We have known for a long time that both elites and the media can matter for opinion change (see, for example, Iyengar, Peters, and Kinder 1982). Because the Court does so little, relative to elected leaders, to communicate its messages, the role of the media is quite different. Further, scholars have shown that we should expect a more deferential role for the media when they cover the Court than when they cover other elite actors (for example, Slotnick and Segal 1998, pp. 18-21; Sill, Metzgar, and Rouse 2013, p. 61). The media are said to acknowledge their role in helping the justices and the Court maintain institutional legitimacy in the eyes of the public (Davis 1994, p. 20).

Given these distinctive circumstances surrounding the Court and the media, it is essential to consider the two together in a study of opinion change, and ours is one of the first studies to explicitly test interactions of any type between elites and the media. Groeling and Baum (2008) is perhaps the most theoretically similar to this study, and it focuses on how deferential media coverage of the president affects opinion. Yet its theoretical mechanism and empirical design are quite distinct from ours. The authors suggest that when a president declares war, media look for but cannot find competing messages from opposition politicians. In contrast, we suggest that competing messages exist following controversial court decisions but that the media simply spend more time explaining the decision in the Court's terms and using the Court's frames before proceeding to these competing messages. Focusing on the Court specifically, scholars have hypothesized that the way media choose to convey its decisions to the public should matter for opinion change (for example, Clawson and Waltenburg [2003], who experimentally test the impact of media frames about affirmative action, and Stoutenborough, Haider-Markel, and Allen [2006], who note how coverage of gay-rights cases differs between media outlets), but we are the first to test these claims.

These findings also have important and largely reassuring implications for the field of political communication. The scarcity of findings from natural settings in this area is likely because of the difficulty of fielding the appropriate studies. That is, we believe that we find endorsement and framing effects where prior scholars did not because we are able to anticipate major events that received extensive and varied news coverage and connect individual respondents' television exposure to their opinion shifts. We also add to a new literature on pretreatment effects and suggest that, just as repetition of information in the course of an experiment tends not to increase the size of treatment effects, repetition of informa- 
tion in two settings (TV coverage and an experiment) does not increase treatment effects.

\section{REFERENCES}

Ackerman, Bruce. 1991. Foundations. Vol. 1 of We the People. Cambridge, MA: Harvard University Press.

Barabas, Jason, and Jennifer Jerit. 2009. Estimating the Causal Effects of Media Coverage on Policy-Specific Knowledge. American Journal of Political Science 53:73-89.

- 2010. Are Survey Experiments Externally Valid? American Political Science Review 104:226-42.

Bartels, Brandon L., and Diana C. Mutz. 2009. Explaining Processes of Institutional Opinion Leadership. Lournal of Politics 71:249-61.

Bennett, W. Lance. 1996. An Introduction to Journalism Norms and Representations of Politics. Political Communication 13:373-84.

Bowles, Dorothy A., and Rebekah V. Bromley. 1992. Newsmagazine Coverage of the Supreme Court during the Reagan Administration. Lournalism and Mass Communication Ouarterly 69:948-59.

Brickman, Danette, and David A. M. Peterson. 2006. Public Opinion Reaction to Repeated Events: Citizen Response to Multiple Supreme Court Abortion Decisions. Political Behavior 28:87-112.

Caldeira, Gregory A. 1986. Neither the Purse nor the Sword: Dynamics of Public Confidence in the Supreme Court. American Political Science Review 80: 1209-26.

Caldeira, Gregory A., and James L. Gibson. 1992. The Etiology of Public Support for the Supreme Court. American Journal of Political Science 36:635-64.

Chong, Dennis, and James N. Druckman. 2007. Framing Public Opinion in Competitive Democracies. American Political Science Review 101:637-55.

—. 2011. Identifying Frames in Political News. Pp. 238-67 in Sourcebook for Political Communication Research: Methods, Measures, and Analytical Techniques, edited by Erik P. Bucy and R. Lance Holbert. New York: Routledge.

- 2013. Counterframing Effects. Iournal of Politics 75:1-16.

Clawson, Rosalee A., Elizabeth R. Kegler, and Eric N. Waltenburg. 2001. The Legitimacy-Conferring Authority of the US Supreme Court. American Politics Research 29:566-91.

Clawson, Rosalee A., and Eric N. Waltenburg. 2003. Support for a Supreme Court Affirmative Action Decision: A Story in Black and White. American Politics Research 31:251-79.

Dahl, Robert A. 1957. Decision-Making in a Democracy: The Supreme Court as a National Policy-Maker. Journal of Public Law 6:279-95. 
Davis, Richard. 1987. Lifting the Shroud: News Media Portrayal of the US Supreme Court. Communications and the Law 9:43-59.

- 1994. Decisions and Images: The Supreme Court and the Press. Englewood Cliffs, NJ: Prentice-Hall.

DellaVigna, Stefano, and Ethan Kaplan. 2007. The Fox News Effect: Media Bias and Voting. Ouarterlv Journal of Economics 122:1187-1234.

Druckman, James N. 2001. The Implications of Framing Effects for Citizen Competence. Political Behavior 23:225-56.

Druckman, James N., and Thomas J. Leeper. 2012. Learning More from Political Communication Experiments: Pretreatment and Its Effects. American Journal of Political Science 56:875-96.

Egan, Patrick J., and Jack Citrin. 2011. The Limits of Judicial Persuasion and the Fragility of Judicial Legitimacy. Unpublished manuscript. New York University, Department of Politics, New York.

Fox, Justin, and Matthew C. Stephenson. 2011. Judicial Review as a Response to Political Posturing. American Political Science Review 105:397-414.

Franklin, Charles H., and Liane C. Kosaki. 1989. Republican Schoolmaster: The U.S. Supreme Court, Public Opinion, and Abortion. American Political Science Review 83:751-71.

1995. Media, Knowledge, and Public Evaluations of the Supreme Court. Pp. 352-75 in Contemplating Courts, edited by Lee Epstein. Washington, DC: CQ Press.

Gash, Alison, and Angelo Gonzales. 2008. School Prayer. Pp. 62-79 in Public Opinion and Constitutional Controversy, edited by Nathaniel Persily, Jack Citrin, and Patrick J. Egan. New York: Oxford University Press.

Gerber, Alan, Dean S. Karlan, and Daniel Bergan. 2009. Does the Media Matter? A Field Experiment Measuring the Effect of Newspapers on Voting Behavior and Political Opinions. American Economic Journal: Applied Economics $1: 35-52$.

Graber, Doris A. 2004. Mediated Politics and Citizenship in the Twenty-First Century. Annual Review of Psychology 5 5:545-71.

Groeling, Tim. 2008. Who's the Fairest of Them All? An Empirical Test for Partisan Bias on ABC, CBS, NBC, and Fox News. Presidential Studies Ouarterlv 38:631-57.

Groeling, Tim, and Matthew A. Baum. 2008. Crossing the Water's Edge: Elite Rhetoric, Media Coverage, and the Rally-round-the-Flag Phenomenon. Lournal of Politics 70:1065-85.

Hanley, John. 2008. The Death Penalty. Pp. 108-38 in Public Opinion and Constitutional Controversy, edited by Nathaniel Persily, Jack Citrin, and Patrick J. Egan. New York: Oxford University Press.

Hoekstra, Valerie J. 1995. The Supreme Court and Opinion Change: An Experimental Study of the Court's Ability to Change Opinion. American Politics 
Research 23:109-29.

- 2003. The Supreme Court and Local Public Opinion. New York: Cambridge University Press.

Hoekstra, Valerie J., and Jeffrey A. Segal. 1996. The Shepherding of Local Public Opinion: The Supreme Court and Lamb's Chapel. Lournal of Politics 58:1079-1102.

Iyengar, Shanto, and Kyu S. Hahn. 2009. Red Media, Blue Media: Evidence of Ideological Selectivity in Media Use. Iournal of Communication 59:19-39.

Iyengar, Shanto, Donald R. Kinder, Mark D. Peters, and Jon A. Krosnick. 1984. The Evening News and Presidential Evaluations. Lournal of Personality and Social Psychology 46:778-87.

Iyengar, Shanto, Mark D. Peters, and Donald R. Kinder. 1982. Experimental Demonstrations of the "Not-So-Minimal" Consequences of Television News Programs. American Political Science Review 76:848-58.

Jerit, Jennifer, Jason Barabas, and Toby Bolsen. 2006. Citizens, Knowledge, and the Information Environment. American Iournal of Political Science 50:26682.

Johnson, Timothy R., and Andrew D. Martin. 1998. The Public's Conditional Response to Supreme Court Decisions. American Political Science Review 92: 299-309.

Kaiser Family Foundation. 2013. Kaiser Health Tracking Poll: March 2013. March 20. http://kff.org/health-reform/poll-finding/march-2013-tracking-poll.

Katsh, Ethan. 1983. The Supreme Court Beat: How Television Covers the US Supreme Court. Judicature 67:6-11.

Kinder, Donald R. 2007. Curmudgeonly Advice. Lournal of Communication 57: 155-62.

Kramer, Larry. 2004. The People Themselves: Popular Constitutionalism and Judicial Review. Oxford: Oxford University Press.

Kuklinski, James H., and Norman L. Hurley. 1994. On Hearing and Interpreting Political Messages: A Cautionary Tale of Citizen Cue-Taking. Lournal of Politics 56:729-51.

Le, Loan, and Jack Citrin. 2008. Affirmative Action. Pp. 162-83 in Public Opinion and Constitutional Controversy, edited by Nathaniel Persily, Jack Citrin, and Patrick J. Egan. New York: Oxford University Press.

Luks, Samantha, and Mike Salamone. 2008. Abortion. Pp. 80-107 in Public Opinion and Constitutional Controversy, edited by Nathaniel Persily, Jack Citrin, and Patrick J. Egan. New York: Oxford University Press.

Marshall, Thomas R. 1987. The Supreme Court as an Opinion Leader: Court Decisions and the Mass Public. American Politics Research 15:147-68.

Meader, Aimee. 2013. Is Ideological Coverage on Cable Television an Ethical Journalistic Practice? An Examination of Duty, Responsibility, and Consequence. Lournal of Mass Media Ethics 28:1-14. 
Nelson, Thomas E., Rosalee A. Clawson, and Zoe M. Oxley. 1997. Media Framing of a Civil Liberties Conflict and Its Effect on Tolerance. American Political Science Review 91:567-83.

Nicholson, Stephen P. 2003. The Political Environment and Ballot Proposition Awareness. American Journal of Political Science 47:403-10.

Page, Benjamin I., Robert Y. Shapiro, and Glenn R. Dempsey. 1987. What Moves Public Opinion? American Political Science Review 81:23-43.

Persily, Nathaniel, Gillian E. Metzger, and Trevor W. Morrison, eds. 2013. The Health Care Case: The Supreme Court's Decision and Its Implications. New York: Oxford University Press.

Pew Research Center. 2011. Internet Gains on Television as Public's Main News Source. January 4. http://www.people-press.org/2011/01/04/internet-gains-on -television-as-publics-main-news-source.

Price, Vincent, and Edward J. Czilli. 1996. Modeling Patterns of News Recognition and Recall. Lournal of Communication 46:55-78.

Rosenberg, Gerald N. 1991. The Hollow Hope: Can Courts Bring about Social Change? Chicago: University of Chicago.

Saad, Lydia. 2013. In U.S., 52\% Back Law to Legalize Gay Marriage in 50 States. Gallup Politics. July 29. http://www.gallup.com/poll/163730/back-law-legalize -gay-marriage-states.aspx.

Sill, Kaitlyn L., Emily T. Metzgar, and Stella M. Rouse. 2013. Media Coverage of the U.S. Supreme Court: How Do Journalists Assess the Importance of Court Decisions? Political Communication 30:58-80.

Simon, Dan, and Nicholas Scurich. 2011. Lay Judgments of Judicial Decision Making. Lournal of Empirical Legal Studies 8:709-27.

Slotnick, Elliot E., and Jennifer A. Segal. 1998. Television News and the Supreme Court: All the News That's Fit to Air? New York: Cambridge University Press.

Solimine, Michael E. 1980. Newsmagazine Coverage of the Supreme Court. $\underline{\text { Lour- }}$ nalism and Mass Communication Ouarterly 57:661-63.

Spill, Rorie L., and Zoe M. Oxley. 2003. Philosopher Kings or Political Actors? How the Media Portray the Supreme Court. Judicature 87:22-29.

Stephenson, Matthew C. 2004. Court of Public Opinion: Government Accountability and Judicial Power. Lournal of Law, Economics, and Organization 20: 379-99.

Stoutenborough, James W., Donald P. Haider-Markel, and Mahalley D. Allen. 2006. Re-assessing the Impact of Supreme Court Decisions on Public Opinion: Gay Civil Rights Cases. Political Research Ouarterly 59:419-33.

Stroud, Natalie Jomini. 2011. Niche News: The Politics of News Choice. Oxford: Oxford University Press.

Tushnet, Mark V. 2005. The NAACP's Legal Strategy against Segregated Education, 1925-1950. 2nd ed. Chapel Hill: University of North Carolina Press.

Zaller, John R. 1992. The Nature and Origins of Mass Opinion. New York: Cambridge University Press. 